В статье приведено описание вещественного состава пород салиховской свиты, вскрытых новой Красноусольской скважиной (КУ) в Предуральском краевом прогибе. По литолого-минералогическим признакам дано сопоставление отложений салиховской свиты востока Русской плиты с аналогичными образованиями куккараукской свиты складчатого Урала.

Ключевые слова: салиховская, куккараукская, свита, минералогия.

\title{
DOI: 10.17072/chirvinsky.2021.236
}

Впервые вендские отложения были выделены Б.С. Соколовым в 1950 году. Страторегионом вендской системы является ВосточноЕвропейская платформа (ВЕП), а опорные (ключевые) разрезы венда установлены в складчатой области на Южном Урале (ЮУ).

При корреляции геологических разрезов отложений платформы и складчатых областей важная роль принадлежит маркирующим горизонтам, выделяемым по литолого-стратиграфическим, минералогическим, геохронологическими и другим признакам.

Для венда Южного Урала надежным маркирующим горизонтом служат конгломераты куккараукской свиты, а на сопредельной территории Русской плиты - аналогичные образования салиховской свиты [6;2].

Новые данные по строению разреза и вещественному составу пород маркирующей салиховской свиты получены в результате бурения в 2019 году глубокой (забой 4100 м) Красноусольской (КУ) скважины в Предуральском краевом прогибе. В разрезе этой скважины получен интересный материал по геологическому строению территории, на которой ранее не проводилось бурение глубоких скважин. Полученные материалы позволили выявить литолого-минералогические особенности рассматриваемого маркера и провести сопоставление с куккараукской свитой уральского стратотипа.

(C) С.А. Солодова, 2021 


\section{Литолого-минералогическая характеристика отложений.}

Салиховская свита является базальной свитой шкаповской серии венда. Она выделена К.Р. Тимергазиным в 1953 году со стратотипом в скважине 51 Салиховская (инт. 2955-3036 м). Её разрезы вскрыты во многих скважинах Шкапово-Шиханской впадины, но наиболее полно свита представлена в скважинах 184 и 188 на Южно-Тавтимановской разведочной площади, где она сложена коричнево-бурыми полимиктовыми гравийными песчаниками и гравелитами с маломощными прослоями мелкогалечных конгломератов и имеет мощность 370 м.

В новой Красноусольской скважине салиховская свита выделена в интервале глубин 2360-2575 м и сложена преимущественно песчаниками и конгломератами, подчинены алевролиты и аргиллиты.

Песчаники полимиктовые, разнозернистые (от мелко- до крупнозернистых), темно-вишневые с прослоями желтовато-серых разностей, массивные, с глинистыми обломками зеленовато-серого цвета. Для песчаников характерна слоистость, обусловленная тонкими слойками, обогащенными темно-вишневым глинистым материалом, и единичными прослоями (3-4 см) темно-вишневых аргиллитов. В аргиллитах наблюдаются зеркала скольжения.

Конгломераты мелко- и крупногалечные (размер галек от $0,5 \times 0,5$ см до $3 \times 5$ см) с песчано-гравийным заполнителем желтовато-светло-серого цвета (рис. 1 б). Сортировка галечного материала слабая, гальки преимущественно окатанные. Состав галек: жильный кварц молочнобелый и розовый; темно-серые кремнистые обломки сургучно-красного яшмоидного облика; кварциты буровато-красные; присутствуют единичные гальки песчаников аркозовых, разнозернистых.

В конгломератах наблюдается градационная слоистость: в средней части конгломераты обогащены крупными гальками, а в верхней и нижней частях слоя - сконцентрированы более мелкие гальки. Сгруженность галечного материала различная: в средней части слоя галька к гальке плотно примыкает и количество заполнителя минимально. В основании и кровле конгломератового слоя сгруженность гальки уменьшается, а количество заполнителя увеличивается.

В составе пород свиты подчиненное значение имеют темно-вишневые полимиктовые алевролиты и аргиллиты, часто линзовидно-выклинивающиеся. В породах наблюдаются субвертикальные трещинки, залеченные белым кальцитом. Мощность свиты 215 м.

При изучении минералогического состава терригенных пород использован метод тяжелых фракций (искусственных шлихов) проб-протолочек. Результаты количественно-минералогического анализа шлихов 

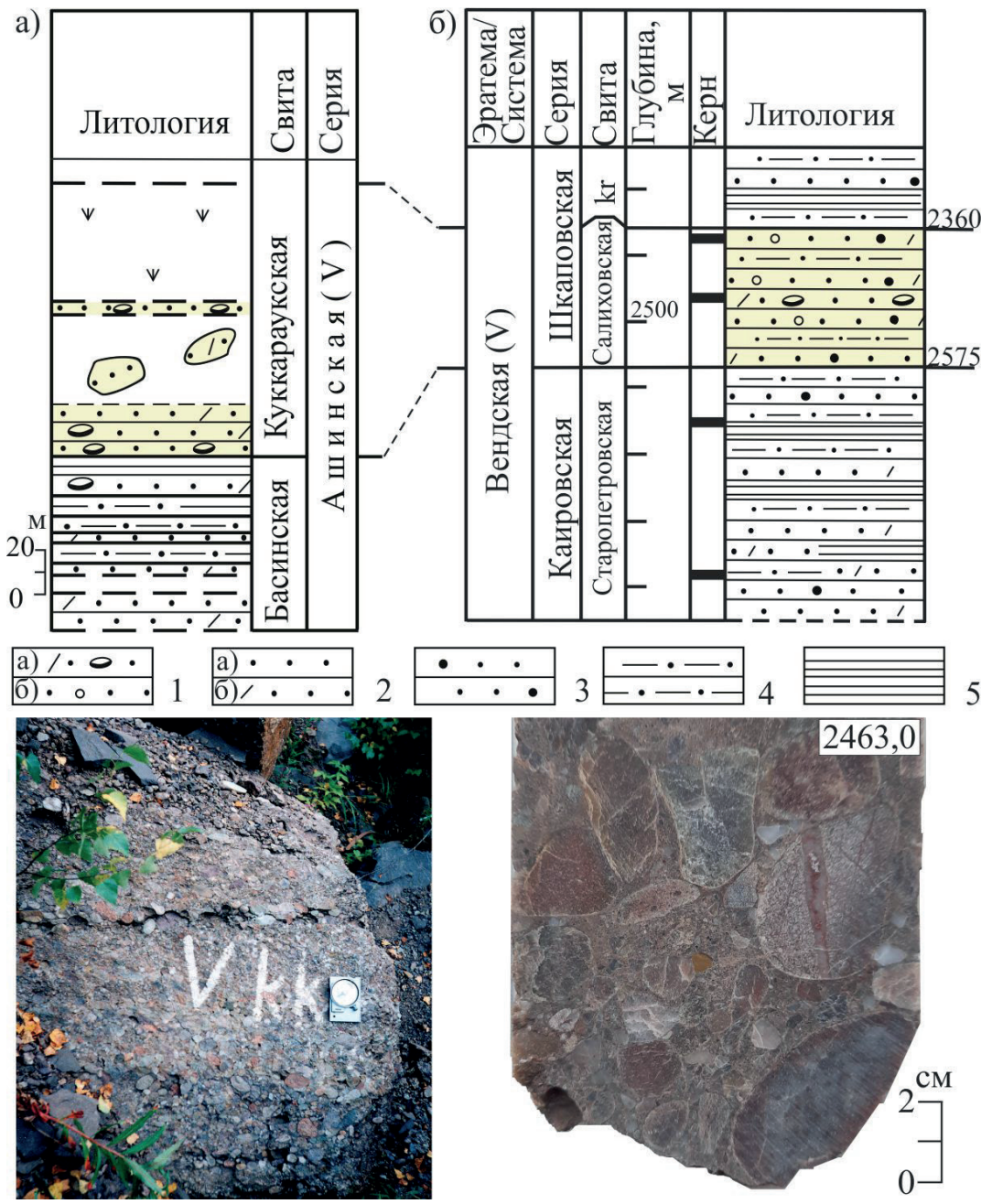

Рис. 1. Разрезы отложений куккараукской свиты по автотрассе Уфа-Инзер западнее р. Зуячка [3] (а) и салиховской свиты, вскрытой Красноусольской скважиной КУ [5] (б).

Условные обозначения: 1 - конгломераты (а), гравеллиты (б); 2-3 песчаники: 2 - песчаники кварцевые (а), полимиктовые (б); 3 - аркозовые (б); 4 - алевролиты; 5 - аргиллиты. 
приведены в таблице 1, где содержание минералов выражается в граммах на тонну (г/т).

Основное содержание тяжелой фракции составляют турмалин, циркон, слюда, реже апатит (продукты разрушения кислых пород), из минералов метаморфических пород большим содержанием выделяются гранат, лейкоксен, эпидот, рутил встречен только в пробах с глубины 2372 и 2374,6 м. Из минералов - спутников основного и ультраосновного состава присутствуют ильменит (147 г/т), реже магнетит (1 г/т) и хромшпинелиды.

Из аутигенных минералов значительным содержанием выделяется гематит (1254 г/т), меньше пирит, хлорит.

Особенное внимание уделено таким акцессорным минералам, как циркон, апатит, турмалин, гранат и рутил, ввиду их информативности.

Таблица 1

Содержание минералов тяжелой фракции в отложениях салиховской $и$ куккараукской свит $(2 / \mathrm{m})$

\begin{tabular}{|c|c|c|}
\hline Скважины/обнажения & Красноусольская & Р. Зуячка \\
\hline Кол-во проб & 8 & 7 \\
\hline \multicolumn{3}{|c|}{ минералы кластогенные } \\
\hline Циркон & 106 & 136 \\
\hline Апатит & 26 & 10 \\
\hline Турмалин & 420 & 286 \\
\hline Гр. слюд & 523 & 884 \\
\hline Магнетит & 1 & - \\
\hline Гр. пироксена & 119 & 17 \\
\hline Ильменит & 147 & + \\
\hline Рутил & 9 & 82 \\
\hline Лейкоксен & 219 & 22 \\
\hline Гр. амфибола & 14 & 17 \\
\hline Гр. эпидота & 49 & 416 \\
\hline Гр. граната & 130 & 533 \\
\hline \multicolumn{3}{|c|}{ Аутигенные } \\
\hline Пирит (марказит) & 16 & 9 \\
\hline Гр. карбоната & 6 & - \\
\hline Хлорит & 1 & 217 \\
\hline Гематит (мартит) & 1254 & 976 \\
\hline
\end{tabular}

Примечание: (+) - Минерал присутствует как редкие зерна. 
Основные акцессорные минералы образуют рутил-апатит-цииркон-гранат-турмалиновую ассоциацию. Руководящими минералами в ассоциации (выделены курсивом) служат турмалин, гранат и циркон, имеющие следующие особенности:

Циркон встречен преимущественно в виде хорошо окатанных зерен, реже встречаются призматические кристаллы цирконового типа хорошей сохранности, некоторые со сглаженными ребрами и гранями. Окраска цирконов от бледно-розовой до розовой. Размеры варьируют от $0,05 \times 0,075$ мм до $0,15 \times 0,25$ мм.

Турмалин представлен в виде призматических кристаллов, а также окатанных шаровидных зерен (чаще черного цвета). Цвет от серо-коричневого до почти черного. Размеры зерен колеблются от 0,05х0,05 мм до $0,25 \times 0,3$ мм.

Гранат присутствует в виде кристаллов додекаэдра, а также угловатых обломков неправильной формы, иногда со ступенчатыми поверхностями граней. Цвет бледно-розовый. Размер зерен - 0,075х0,1 мм; 0,15х0,225 мм.

Куккараукская свита на Южном Урале выделяется на западном крыле Башкирского мегантиклинория. Свита впервые выделена А.И. Олли в 1940 г. со стратотипом по руч. Куккараук. С подстилающей басинской свитой куккараукская связана постепенным переходом [1]. Мощность ее отложений 100-300 м.

Куккараукская свита сложена вверху и внизу песчаниками полимиктовыми, разнозернистыми, с прослоями гравелитов, а в средней части - разногалечными полимиктовыми конгломератами (см. рис. 1 a). Преобладающие в составе пород и в матриксе конгломератов песчаники крупно- и среднезернистые, плохо сортированные, с гравием и редкой галькой. Конгломераты полимиктовые, разногалечные, преимущественно мелко- и среднегалечные. Галька хорошо окатанная, эллипсоидальной, реже неправильной формы, представлена кварцем и кварцевыми песчаниками, иногда катаклазированными, кварцито-песчаниками, кварцитами, кварцевыми сиенитами с порфировой структурой, плагиогранитами, гранит-порфирами и крупнокристаллическими гранитами [4].

В комплексе шлиховых минералов из отложений свиты, вскрытых дорожной выемкой по а/трассе Уфа-Инзер в 6 км западнее р. Зуячка, преобладают минералы-спутники кислых (турмалин, циркон, апатит, слюда) и метаморфических (рутил, гранат) пород (см. табл. 1). Из приведенной таблицы следует, что акцессорные минералы образуют апатит-рутил-циркон-турмалин-гранатовую ассоциацию. 
Типоморфные особенности акцессорных минералов:

Гранат представлен полуокатанными зернами неправильной формы и кристаллами ромбододекаэдрического облика, иногда со ступенчатыми гранями, бледно-розовой, иногда с желтоватым и лиловатым оттенками, и розовато-красной окраски. Размеры зерен граната колеблются от $0,1 \times 0,1$ до $0,4 \times 0,4$ мм.

Циркон наблюдается в хорошо окатанных зернах, реже кристаллах со сглаженными ребрами бледно-розовой, меньше розовой и молочно-белой (малаконы) окраски, отмечены единичные зерна темнорозовых разностей. Цирконы содержат газово-жидкие и игольчатые минеральные включения и цирконовые ядра. Размеры зерен циркона варьируют от $0,05 \times 0,1$ мм до $0,15 \times 0,25$ мм.

Anaтum встречается в виде призматических кристаллов, а также в зернах неправильной формы и хорошо окатанных. Апатит бесцветный прозрачный, иногда с минеральными включениями, с размерами зерен от $0,05 \times 0,05$ мм до $0,18 \times 0,3$ мм.

Турмалин присутствует в кристаллах коричневато-бурой окраски и в хорошо окатанных зернах, которые имеют более разнообразную окраску: от светло-бурой до темно-бурой с коричневым и желтым оттенками и голубовато-серую. Размер окатанных зерен варьирует от $0,05 \times 0,075$ до $0,225 \times 0,375$ мм, а размер отдельных кристаллов достигает $0,25 \times 0,325$ мм.

Рутил представлен полуокатанными обломками удлиненной и уплощенной формы, редко кристаллами и коленчатыми двойниками, преимущественно оранжевой и оранжево-желтой окраски. Размер обломков от $0,07 \times 0,07$ мм до $0,2 \times 0,225$ мм.

Таким образом, для куккараукской и её возрастного аналога салиховской свит типоморфными являются полимиктовые песчаники и конгломераты вишнево-серые, красновато- и желтовато-серые. В породах куккараукской свиты выделена апатит-рутил-циркон-турмалингранатовая акцессорно-минеральная ассоциация и в салиховской - рутил-апатит-циркон-гранат-турмалиновая, руководящими минералами в которых служат циркон, турмалин и гранат. Вендские отложения выделяются повышенным содержанием граната, в рифейских толщах гранат встречается очень редко. Морфологические особенности граната (наличие бледно-розовых кристаллов додекаэдра, а также угловатых обломков зерен неправильной формы, иногда со ступенчатыми поверхностями граней) едины как для кукараукских, так и для салиховских песчаников и конгломератов. 


\section{Заключение}

Корреляцией разрезов позднедокембрийских отложений восточной части Русской плиты по данным бурения параметрических и глубоких скважин и в обнажениях на Южном Урале занимались многие исследователи: К.Р. Тимергазин, Б.М. Келлер, В.И. Козлов, Н.Д. Сергеева, Л.Д. Ожиганова и др. Перечисленными исследователями было показано, что в докембрийских осадочных толщах ВЕП и ЮУ выделяются маркирующие толщи, имеющие определенное стратиграфическое положение, состав, строение, специфические литолого-петрографические, минералогические, петро- и геохимические особенности, позволяющие уверенно коррелировать разрозненные и удаленные разрезы.

Для вендских образований такими маркирующими толщами являются песчаники и конгломераты куккараукской и салиховской свит. Для рассматриваемых осадков характерны: преимущественно полимиктовый состав, а для песчаников - полевошпат-кварцевый и реже субаркозовый, аркозовый.

Конгломераты и песчаники куккараукской и салиховской свит, имеющие сходные состав и облик, являются хорошими маркерами, значимость которых возрастает при использовании дополнительно минералогических данных. В породах обеих свит руководящими минералами в акцессорно-минеральных ассоциациях служат циркона, турмалина и граната. Гранат, как основной минерал рассматриваемых отложений, имеет в них сходные типоморфные признаки - бледно-розовые полуокатанные или окатанные зерна неправильной формы и кристаллы ромбододекаэдрического облика, иногда со ступенчатыми гранями. Сходные как литологические, так и минералогические признаки терригенных отложений, формирование которых приурочено к зоне сопряжения платформенной (салиховская свита) и складчатой (куккараукская свита) областей, делает корреляцию отложений более надежной и позволяет предположить, что эти отложения связаны единым осадочным бассейном.

Исследования выполнены в соответствии с планами научно-исследовательских работ Института геологии Уфимского федерального исследовательского иееттра РАН (тема гос. задания № 0246-2019-0087).

Библиографический список

1. Беккер Ю.Р. Молассы докембрия. Л.:Недра. 1988. 288 с.

2. Козлов В.И., Сергеева Н.Д. Верхний протерозой Волго-Уральской области. Стратиграфия и особенности состава // Геология. Известия Отделения наук о Земле и природных ресурсов АН РБ. 2011. № 17. С. 58-80

3. Козлов В.И. Верхний рифей и венд Южного Урала. М.:Наука, 1982. 128 с.

4. Козлова О.В., Ратов А.А., Солодова С.А., Бояркин С.А. Литолого-петрогра- 
фические и минералогические особенности ашинской молассы венда на Южном Урале // Геологический вестник. 2019. № 2. С. 88-101. DOI: http:// doi. org/10.31084/2619-0087/2019-2-7

5. Сергеева Н.Д., Дьяконова О.Б., Козлова О. В. Стратиграфическое расчленение допалеозойских отложений, вскрытых в Предуральском краевом прогибе скважиной 40 Красноусольская // Геология, полезные ископаемые и проблемы геоэкологии Башкортостана, Урала и сопредельных территорий: Материалы и доколады / 13-я Межрегиональная научно-практическая конференция, Уфа, 2022 мая 2020 г. - Уфа: Мир печати, 2020. - 180 с.

6. Стратиграфическая схема рифейских и вендских отложений Волго-Уральской области: Объяснительная записка / Сост. Е.М. Аксенов, В.И. Козлов. Уфа, 2000. 81 с. + схема на 2 л.

\section{LITHOLOGICAL AND MINERALOGICAL FEATURES OF THE DEPOSITS OF THE SALIKHOVSKAYA SUITE IN THE SECTION OF THE NEW KRASNOUSOLSKAYA WELL IN THE CIS-URAL FOREDEEP AND THE KUKKARAUKSKAYA SUITE OF THE SOUTHERN URALS}

\section{S.A. Solodova}

solodowa.sveta2010@yandex.ru

The article provides a description of the material composition of the rocks of the Salikhovskaya formation, exposed by the new well Krasnousolsk in the Preuralian foredeep. Based on lithological and mineralogical features, a comparison is made of the deposits of the Salikhovskaya formation in the east of the Russian plate with similar formations of the Kukkarauk formation of the Urals.

Keywords: Salikhovskaya, Kukkaraukskaya, suite, mineralogy 